\title{
Knowledge, Attitude And Preventive Behavior Towards Toxoplasmosis Among Kuwaiti Women With/Without Pregnancy Experience: A Cross Sectional Study
}

Jamshaid lqbal ( $\sim$ Jamshaid.rafique@ku.edu.kw)

Kuwait University

Najat Khadadah

Kuwait University

Ahmad Mohammed

Kuwait University

\section{Research Article}

Keywords: Toxoplasmosis, Pregnant women, Knowledge, Attitude, Prevalence, Kuwait

Posted Date: September 2nd, 2021

DOl: https://doi.org/10.21203/rs.3.rs-778294/v1

License: (c) (1) This work is licensed under a Creative Commons Attribution 4.0 International License.

Read Full License 


\section{Abstract}

Background: Toxoplasmosis is caused by an obligate intracellular opportunistic protozoan parasite, Toxoplasma gondii, with a worldwide distribution. T. gondii infection among pregnant women during the first trimester may transmit infection to the fetus with serious congenital consequences. No data is available on knowledge, attitude and preventive behavior towards toxoplasmosis among pregnant women in Kuwait. This cross-sectional study evaluated knowledge, attitude, and preventive behavior towards toxoplasmosis among women in Kuwait, and reviewed the situation in the Middle east.

Methods: Data related to socioeconomic status, knowledge and attitude towards toxoplasmosis were collected from 326 adult female school/university students, and 86 pregnant women through a selfadministered online questionnaire during 2019-2021. Participants were divided into two main groups: women with pregnancy experience (PEG) and never-pregnant group (NPG).

Results: PEG ( $n=212)$ included 114 currently pregnant and 98 women with history of an earlier pregnancy. NPG included 200 subjects. All participants belonged to a medium-to-high social status and minimum high school education. Nearly $50 \%$ of PEG women had inadequate knowledge towards toxoplasma infection, and only $33(15.6 \%)$ knew its mode of transmission compared to $35(17.5 \%)$ in the NPG $(P=0.597)$. A significantly higher number of women in PEG (97 of $212,45.8 \%)$ knew it can be prevented compared to 66 of $200(33 \%)$ in NPG ( $P=0.008)$. Only 35 (16.5\%) of PEG women knew about screening tests for toxoplasma infection, and their main source of information on toxoplasmosis was healthcare professionals and family/friends compared with NPG women who got information through newspapers/books. PEG Women exhibited enhanced preventive behavior towards toxoplasmosis. Nearly $50 \%$ of all PEG participants lacked basic knowledge towards toxoplasmosis but $>90 \%$ of them avoided most high-risk activities during their pregnancy. In addition, this is the first study in the Middle east conducted through an online survey to collect relevant information related to toxoplasmosis from pregnant women.

Conclusions: This study highlights inadequate knowledge and preventive behavior towards toxoplasmosis among Kuwaiti women. Thus, health education on toxoplasmosis should be offered to all adult/pregnant women to reduce congenital toxoplasmosis.

\section{Background}

Toxoplasmosis is caused by an obligate intracellular opportunistic protozoan parasite, Toxoplasma gondii, which has a worldwide distribution, affecting about one third of the human population [1]. Humans are infected by ingesting cysts from undercooked meat, or by consuming water or food contaminated with infectious oocysts [2]. The consequences of $T$. gondii infection in humans depend on the genetic background and immunity of the host, and strain and inoculum size of the parasite [1, 3, 4]. Infection with $T$. gondii is usually asymptomatic or may cause a self-limiting flu-like illness, but it may 
lead to severe infection in individuals with supressed immune systems [5]. Seroprevalence of T. gondii infection in humans varies according to age, population group, geographical location, and dietary habits $[6,7]$. In the USA and UK, approximately $16 \%-40 \%$ of the population is infected, and this rate increases further in Central America and Continental Europe where infection rates reach 50\%-80\% [8]. In addition, $T$. gondii can be vertically transmitted during pregnancy from an immunologically naive mother to her fetus, with the prevalence of congenital toxoplasmosis reaching up to 10 per 10,000 live births in some countries/settings [9].

Epidemiological surveys carried out among pregnant women and women of childbearing age have repeatedly shown a considerable variation in the seroprevalence of Toxoplasma infection ranging from $7.5 \%$ to $92.5 \%$ in different parts of the world; $9 \%-11 \%$ in the USA, and $72 \%$ in Brazil [10]. A total of 242 cases of congenital toxoplasmosis were reported in Europe, of which $196(81 \%)$ of the cases were detected in France [11]. The notification rate was 6.7 cases per 100000 live births, with the highest rates in France (24.9 cases) followed by Poland ( 5.2 cases).

Significantly high seroprevalence rates (75\%-92.5\%) were reported from various tropical African countries [12], in contrast to most South Asian countries where T. gondii seroprevalence was relatively moderate to low [13].

However, there has been a decreasing trend of $T$. gondii prevalence in many countries during the last two decades due to lower exposure to the parasite because of better socio-economic conditions, changes in the nutritional habits and improved hygiene practices and knowledge towards the disease [14-16]. Several studies in the Middle East have shown varying seroprevalence of Toxoplasma infection among different Arab nationalities/geographic regions; Mediterranean Arabs (56.4\%), African Arabs (29.3\%) and the Arabian Gulf region (32\%). The prevalence rate of toxoplasmosis in Saudi Arabia varied greatly in different parts of the country [17]. A seroprevalence rate of $27.4 \%$, significantly associated with increasing age was documented among Saudi women of reproductive age in southwestern Saudi Arabia [18].

The State of Kuwait is demographically comprised of a large expatriate population originating mainly from the Asian and Arab countries, comprising nearly $70 \%$ of the total 4.7 million inhabitants (The Public Authority for Civil Information, Kuwait, 2019) [19]. Previous studies in select populations had reported a prevalence of $T$. gondii infection (52\%-95\%) among women of childbearing age in Kuwait [20-22]. However, a more recent study reported a significant decline in prevalence of $T$. gondii infection among pregnant women (12.5\%) [16].

Despite recent report of steady declining trends of toxoplasma infection over the past few decades in Kuwait, there is no information on the knowledge (symptoms, transmission methods, treatment, prevention and control of the disease) and perception towards this disease among women of childbearing age and pregnant women in Kuwait.

The main objective of this study was to review the seroprevalence of toxoplasmosis in the Middle East and to evaluate knowledge, attitude, and preventive behavior towards toxoplasmosis among Kuwait 


\section{Materials And Methods}

\section{Study design and Study Population}

This cross-sectional study was conducted to evaluate socioeconomic status, knowledge, attitude, and preventive behavior towards toxoplasmosis from 326 adult female high school/university students, and 86 pregnant women through a self-administered online questionnaire during October 2019 and February 2021. The target groups for the survey were randomly selected. Participants were divided into two main groups; women with pregnancy experience (PEG) and never-pregnant group (NPG), and the PEG group was subdivided into currently pregnant (CP) and h/o of earlier pregnancy (EP).

\section{Questionnaire}

A structured questionnaire was constructed and used to collect sociodemographic characteristics of the participants, and knowledge, attitude, and practice towards toxoplasma infection from the participants. The questionnaire was pre-tested on a random sample of 25 students to optimize the instrument and to determine the time needed to complete the questionnaire.

The questionnaire was reviewed and edited to ensure that the participants clearly understood the questions. The questionnaire was self-administered and anonymous. Questionnaire items were designed to get the data on socioeconomic status and demographic characteristics of the participants, and to assess the basic knowledge, attitude, and practice of the target groups towards the importance of the disease. All respondents were informed of their ethical and consensual rights and were assured of confidentiality of their identity and responses. The questionnaire consisted of 36 closed-ended questions and took approximately 15 minutes to be completed to obtain information on participant's demographic \& background (6), basic knowledge (6), sources of information (6), preventive measures (6), risk behavior (5), and attitude (8) towards toxoplasmosis.

The survey was conducted online using WhatsApp and telephone.

\section{Sample size}

An online Epi Info ${ }^{T M}$ 7, a public domain set of software tools by Centers for Disease Control and Prevention (CDC), was used to calculate the sample size [23]. For this purpose, we used: a) $20 \%$ as the expected frequency, though no data was available for such a study in Kuwait, b) $5 \%$ of confidence limits, d) and a $95 \%$ confidence level. The calculated sample size was 374 subjects.

A total of 412 randomly selected adult females participated in the online survey, the target groups included pregnant women attending the antennal clinics $(n=86)$ at any gestational stage, adult graduating students at a Mishref Public high school $\geq 18$ years of age $(n=57)$, and undergraduate students at the Faculties of Medicine, $1^{\text {st }}$ Year students $(n=54)$, Engineering \& Petroleum $(n=76)$, Business 
Administration $(n=75)$, and Social sciences $(n=64)$. However, for data analysis and discussion, the participants were divided into two main groups; women with pregnancy experience (PEG, $n=212)$ and never-pregnant group (NPG, $n=200)$; PEG group was subdivided into currently pregnant $(C P, n=114)$ and women with history of an earlier pregnancy $(E P, n=98)$.

\section{Data Management and Statistical Analysis}

The survey data were coded and entered in Microsoft Excel spread sheets and descriptive and analytic statistics were computed using SPSS Version 20. Chi square test $(X 2)$ and Fisher's Exact test were employed to see the association of demographic history with knowledge of the respondents. A $P$-value less than 0.05 was considered as statistically significant.

\section{Ethical Approval}

The participation in this study/survey was voluntary and answer to the survey was in anonymous mode. The Ethical Committee for the Protection of Human Subjects in Research, Kuwait University, and the Ministry of Health, under reference no. 187/2014, indicated that the study does not require ethics approval, as it does not contain any personal data of the participants. The questionnaire was anonymous. All respondents were informed about the objective of the study and informed consent was obtained from all respondents and confidentiality of their identity and responses was assured.

\section{Results}

A total of 412 randomly selected adult females participated in the online survey about toxoplasmosis to evaluate their socioeconomic status, knowledge, attitude, and preventive behavior towards toxoplasmosis between October 2019 and February 2021. The age of the female students at the High school, University students and pregnant women attending the antenatal clinic ranged between 18-19 years, 19-25 years, and 20-41 years respectively. Most participants, 175 (42.5\%), were in the 18-20 years of age range followed by $126(30.6 \%)$ in the 21-25-year age range. Only $17(4.1 \%)$ participants were $>40$-year-old. At the time of survey, most of the students 298 of $326(91.4 \%)$ were unmarried. A total of $114(27.7 \%)$ participants were currently pregnant, including 28 among the students. A total of 17 of the currently pregnant participants (14.9\%) also gave a history of abortion in the past. Of the 44 of $86(51.2 \%)$ pregnant women attending the antennal clinics had a university degree. Almost all participants belonged to medium-to-high social status and lived in urban areas.

In terms of statistical analysis and description about knowledge and preventive behavior towards toxoplasmosis, the participants were divided into two main groups: women with pregnancy experience group (PEG) and never-pregnant group (NPG). The PEG ( $n=212,51.5 \%)$ included 114 currently pregnant (CP) and 98 females with history of an earlier pregnancy (EP), and NPG had ( $n=200,48.5 \%)$ participants. Concerning 'what do you know about toxoplasmosis: I know nothing', there was no significant difference between the two groups, $50.5 \%$ of the women in the PEG compared to $41.5 \%$ in NPG (Chi-square $p$-value $=0.067$ ), Figure 1a. No significant difference was noted between the NP and EP 
women $(p<0.93)$ for I know nothing on toxoplasmosis. Of the NPG, the high school girls were least informed (36.6\%) compared to $1^{\text {st }}$ Year medical students (11.9\%) (Figure 1b), whose main source of information towards toxoplasmosis was newspaper and books.

Though only 33 (15.6\%) of the women in PEG knew its mode of transmission compared to women in NPG 35 (17.5\%) (Chi-square p-value= 0.597, > 0.05), a significantly higher number of women in the PEG, 97 (45.8\%) knew it can be prevented compared to women in NPG, 66 (33.0\%) (Chi-square p-value= 0.008, $<0.05$ ), as presented in Figure 2. Within the PEG group, EP women selected 'I know how it is transmitted and how it can be prevented' as frequent as those who were currently pregnant ( $\mathrm{P}$-value $=0.071$ and 0.611 respectively) (Figure 3).

Overall, $16.5 \%(\mathrm{n}=35)$ of the women in PEG knew about knowledge on the screening tests for toxoplasma infection, compared to $12.0 \%(n=24)$ of women in NPG, there was no statistical difference between the two groups (Chi-square $p$-value $=0.192,>0.05$ ). Within the NPG, $1^{\text {st }}$ year medical students were the most informative about the screening test $(31.5 \% 0$ followed by the students in Social sciences $(23.4 \%)$ and Engineering faculty (22.4\%) (Figure 4).

With respect to the source of knowledge, there was significant difference between the two groups, a significantly higher number of women in PEG got this information from health care professionals $(26.9 \%$ vs. $7 \%$, Chi-square $p$-value $=0.000,<0.001)$, and family members and friends $(24.1 \%$ vs. $14.5 \%$, Chi-square $p$-value $=0.014,<0.05$ ) compared with the women in NPG, Figure 5 . Social media was the least source of information for all the groups.

With respect to determine the attitude of participants towards toxoplasma infection transmission by not getting involved in high-risk activities, $>90 \%$ of women in both the groups avoided most of the high-risk activities, however, women in PEG were more likely to avoid changing the cat litter box ( $p$-value 0.004 ) or eat under cooked meat ( $p$-value 0.001) (Table 1).

Overall, $56.5 \%$ of the women in NPG knew nothing about the characteristics of toxoplasmosis compared to $45.3 \%$ of the women in PEG ( $p$-value $=0.023$ ). $12 \%$ of the women in NPG selected that toxoplasmosis could be transmitted by blood transfusion compared to $4.7 \%$ in the women in the PEG ( $p$-value $=0.007$ ). On the other hand, $46.7 \%$ of the women in PEG knew that toxoplasmosis is dangerous compared to $37 \%$ of the women in NPG ( $\mathrm{p}$-value $=0.046)$, as shown in Table 1 .

The data collection through online survey was quick, cost-effective and most of the participants felt comfortable in their spontaneous responses to the questionnaire.

\section{Discussion}

Several epidemiological surveys have repeatedly shown a considerable prevalence of Toxoplasma infection among pregnant women and women of childbearing age, though several studies have also reported a decreasing trend of $T$. gondii prevalence, both in general population and in pregnant 
women in many countries during the last two decades [14-16,24]. A recent systematic review \& metaanalysis of 21 studies during the period 1996-2018 showed an overall IgG toxoplasma seroprevalence of $35.0 \%$ in public and $29.0 \%$ among pregnant women worldwide [25], and another analysis of 36 studies during the period 1979-2018 showed an overall IgG seroprevalence rate of 39.7\% (range $21.0 \%-38.8 \%$ ) among pregnant women in the countries of Eastern Mediterranean region (EMRO) [24]. However, very high rates were reported from some countries in Africa, Namibia (74.3\%), South Africa (70.1\%), and Algeria (67.5\%) [24]. This variation in the rate of $T$. gondii infection between countries and regions could be attributed to different sociodemographic characteristics such as dietary habits, education and health standards and lack of knowledge and attitude towards disease transmission and prevention. Table 2 shows an updated list on seroprevalence of $T$. gondii IgG and IgM antibodies and associated risk factor among pregnant women \& women of childbearing age in countries of the Eastern Mediterranean \& African Region [16,22,24-52]. A number of toxoplasma associated risk factors were reported across the Middle east, contact with cat, eating undercooked meat and raw vegetables and older age group (Table 2), however, studies from Kuwait and Nigeria reported no significant risk factors [16,49].

Recently, we reported a significantly lower toxoplasma seroprevalence rate of $12.5 \%$ among pregnant women in Kuwait compared to $53.1 \%$ reported more than a decade ago [16,22]. Similar decreasing trends were also reported among pregnant women in Saudi Arabia (from 38.8\% in 2014 to 21.2\% in 2021) and Iran (from $39.2 \%$ to $20.1 \%$ in 2021 ) (Table 2 ) $[27,32,40,42]$.

To our knowledge, no previous study has investigated the knowledge and attitude of adult women and pregnant women in Kuwait towards toxoplasma infection and its associated risk factors. It is worth noting that in this study, an experience of an earlier pregnancy was also considered while determining the knowledge, attitude and preventive behavior towards toxoplasmosis and its associated risk factors. In our survey, all women in NP, EP \& CP group had inadequate knowledge on the mode of transmission of toxoplasma infection. However, significantly higher number of CP \& EP women had heard about toxoplasmosis and showed positive attitude towards toxoplasma infection prevention than the NP women ( $p$-value $<0.05$ ). Though the number of cases in our data were relatively few, however, our data shows that a pregnancy experience does influence/change women's behavior and attitude towards toxoplasma infection and thus, they avoid major risk factors associated with toxoplasma infection, even without having an appropriate knowledge about mode of transmission of toxoplasmosis (the data and figures are presented as supplementary files). Multiple studies have reported earlier that pregnant state itself does influence the knowledge and attitude of women towards toxoplasmosis [53-56]. Table 3 shows toxoplasmosis-related knowledge and preventive practices from several countries in the Middle east [17,31,37,53-61]. In addition, this is the first study in the Middle east conducted through an online survey to collect information on sociodemographic status and toxoplasmosis related knowledge and preventive practices among pregnant women and women of childbearing age. The data collection through online survey was quick cost-effective and the participants were more comfortable in their spontaneous responses to the questionnaire as compared to the traditional methods. Similar observations were reported in an earlier study conducted through an online survey [62]. 
This study showed that $41.5 \%$ of the women in the pregnant at-least once group had not heard about toxoplasmosis compared with 50.5\% never-pregnant women and that, only $33(15.6 \%)$ of the women in the pregnant-at least-once group knew its mode of transmission compared to the never-pregnant group $35(17.5 \%)$ thus, they may be at a higher risk of possibly being exposed to contracting infection in pregnancy. It is worth noting that in this study, an experience of an earlier pregnancy was also considered while determining knowledge, attitude and preventive behavior towards toxoplasmosis and its associated risk factors. Multiple studies have reported earlier that pregnant state itself does influence the knowledge and attitude of women towards toxoplasmosis $[53,55,56]$.

A literature review of studies from the Middle east countries have reported even higher number of pregnant women ignorant of this infection, as presented in table 3. Several recent studies from the neighboring country Saudi Arabia showed that only 234 (26.8\%) of the pregnant women attending antenatal clinic in Al Hassa knew about modes of transmission of toxoplasma infection, many knew cat as a risk factor, but the majority lacked the necessary preventive behavior [53]. In another study, $75.5 \%$ of the 400 pregnant women attending antenatal clinic in Dharan, Saudi Arabia had never heard about toxoplasmosis and associated risk factors [31]. A recent cross-sectional study conducted on a random sample of 440 female students at Jazan University, Saudi Arabia found that more than three-quarters (79.1\%) of the students had insufficient knowledge about toxoplasmosis and its mode of transmission [17]. A community-based cross-sectional study carried out in Ahvaz County, Iran in 2017 showed that $31.3 \%$ of the public had the basic knowledge on toxoplasma infection transmission and regarded close contact with cats as a high risk for toxoplasma infection transmission [57]. In 2016, 75.2\% of the pregnant women surveyed in Tikrit city in north-central Iraq had no or inadequate knowledge on toxoplasma infection transmission and consequences of infection during pregnancy [63]. A multinational study conducted among 2598 pregnant women from Malaysia, Philippines and Thailand reported similar data [64].

In this study, the high school girls were the least informed (35.1\%) of the knowledge towards toxoplasmosis compared to other University female students. The $1^{\text {st }}$ year medical female students were the most informed student group (77.5\%) than the students from the Faculties of Engineering \& Petroleum (48.0\%), Social Sciences (47.3\%) and Business administration (39.0\%), however, the differences were not statistically significant. Two recent cross-sectional studies showed that $20.9 \%$ of the 440 female students at Jazan University, Saudi Arabia and only 3.2\% of the 1079 female Beni-Suef University students in Egypt had adequate knowledge about toxoplasmosis and its mode of transmission $[17,54]$.

Only $33(15.6 \%)$ of the pregnant women knew its mode of transmission, however, a significantly higher number of pregnant women 97 (45.8\%) knew it can be prevented, and $>90 \%$ of the pregnant and nonpregnant women exhibited a positive attitude towards toxoplasma infection prevention by avoiding high risk activities of changing the cat litter box or eating under cooked meat. Despite lack of knowledge about toxoplasmosis, a relative positive attitude towards toxoplasma infection transmission prevention has been reported by other studies. A cross-sectional study showed that only $3.2 \%$ of the 1079 female Beni- 
Suef university students in Egypt had adequate knowledge about toxoplasmosis, however, $>70 \%$ of female students reported hand washing after gardening and cleaning cat litter boxes [54]. In another cross-sectional study involving 371 pregnant women in Tanzania's Temeke municipality, though $96 \%$ of the women were unaware of Toxoplasmosis, but $90 \%$ unknowingly observed preventive practices by not eating raw meat [55]. Several factors may be involved in the positive behavioral and lifestyle change towards toxoplasmosis by women during pregnancy and/or with a history of a previous pregnancy by avoiding high risk behavior, even without having an appropriate knowledge about it. Similar hypothesis was presented in an earlier study, that preventive behavior during pregnancy was not necessarily associated with specific knowledge about toxoplasmosis [65].

Regarding the source of knowledge about toxoplasmosis, the main source of information for the women in pregnant group in this study were the health care professionals and family members and friends, social media was the least source of information for all the groups. Several studies have reported similar data, Jones et al, showed that $53 \%$ the pregnant women in the USA received toxoplasma-related information from health care workers and $45 \%$ from family/friends [66], while another study from Minnesota, USA reported $63 \%$ of the pregnant women received information from a doctor and $35 \%$ from family/friends [67]. A recent study from Saudi Arabia also reported similar findings [17].

Socioeconomic status and demographic characteristics have been shown to influence the correct knowledge and attitude of a population or study group towards toxoplasmosis. Earlier, studies have shown that women of childbearing age with higher education level, residence in an urban setting and the number of children had better understanding of the symptoms of toxoplasmosis $[62,68,69,70]$. Almost all participants in this study had higher education level, belonged to medium to high social status and lived in the urban area, however, only $41.5 \%$ of the pregnant women had inadequate knowledge about toxoplasma infection transmission and prevention, and none of them knew about the screening tests to check for the infection. Recently, we have reported a steady declining trend of toxoplasma infection in Kuwait over the past few decades, $12.5 \%$ one of the lowest in the Middle east [16]. We believe that this trend was probably due to high education level and free access to high standard health services.

\section{Conclusion}

This is the first study regarding knowledge and practices about toxoplasmosis among pregnant women and female students at High school and the University in Kuwait. The results of this study showed inadequate knowledge and limited awareness about toxoplasmosis among the participants.

Though only $15.6 \%$ of the pregnant women knew its mode of transmission, a significantly higher number of pregnant women $45.8 \% \mathrm{knew}$ it can be prevented, and $>90 \%$ showed a positive attitude towards infection preventive measures and avoided most of the high-risk activities. The results also showed that online data collection was quick cost-effective, and the participants were more comfortable in their spontaneous responses to the questionnaire as compared to the traditional methods.

\section{Declarations}




\section{Acknowledgement}

We would like to thank all participants who took part in the online survey.

\section{Author contributions}

$\mathrm{Jl}$, NK and AM were part of the working group for this project, and each contributed to the conceptualization and planning of the study, interpretation of data and findings, contributed to the manuscript, and approved the work for publication. In addition, AM analyzed the data, and NK contributed to collecting the online data from the participants. JI also supervised the study.

\section{Funding}

This survey has not received any funding.

\section{Ethics approval and consent to participate}

The participation in this study/survey was voluntary and answer to the survey was in anonymous mode. All participants were informed of the objectives of the study and clearly understood the questions. It was ensured that no subject under 16 years of age participated in the survey. The Ethical Committees for the Protection of Human Subjects in Research, Kuwait University, and the Ministry of Health, under reference no. $187 / 2014$, indicated that the study does not require any special ethics approval, as it does not contain any personal data of the participants. In addition, all methods were carried out in accordance with relevant guidelines and regulations, as dictated by the Kuwait University and Ministry of Health Ethical Committees for the Protection of Human Subjects in Research.

The questionnaire was anonymous. All respondents were informed about the objective of the study and informed consent was obtained from all respondents and confidentiality of their identity and responses was assured.

\section{Availability of data and materials}

The datasets used during the current study are available from the corresponding author.

\section{Competing interests}

The authors declare that they have no competing interests.

\section{Author details}

${ }^{1}$ Department of Microbiology, Faculty of Medicine, Kuwait University, P. O. Box 24923, Safat 13110, Kuwait. ${ }^{2}$ Faculty of Medicine, Kuwait University, P. O. Box 24923, Safat 13110, Kuwait.

\section{References}


1. Weis LM, Dubey JP. Toxoplasmosis: A history of clinical observations. Int J Parasitol. 2009; 39: 895901. https://doi.org/10.1016/j.ijpara.2009.02.004

2. Jones JL, Dubey JP. Foodborne toxoplasmosis. Clinical infectious diseases: an official publication of the Infectious Diseases Society of America. 2012; 55(6): 845-851. https://doi.org/10.1093/cid/cis508

3. Messaritakis I, Detsika M, Koliou M, Sifakis S, Antoniou M. Prevalent genotypes of Toxoplasma gondii in pregnant women and patients from Crete and Cyprus. The American journal of tropical medicine and hygiene. 2008; 79(2): 205-209.

4. Dardé ML. Toxoplasma gondii, "new" genotypes and virulence. Parasite. 2008; 15(3): 366-71. doi: 10.1051/parasite/2008153366. PMID: 18814708

5. Negussie A, Beyene E, Palani S. Toxoplasmosis and Associated Risk Factors in Antenatal Clinic follow up Pregnant Women in Selected Health Institutes of Jigjiga, East Ethiopia. International journal of tropical disease \& health. 2017; 21(3): 1-7. https://doi.org/10.9734/ijtdh/2017/31177

6. Moncada PA, Montoya JG. Toxoplasmosis in the fetus and newborn: an update on prevalence, diagnosis and treatment. Expert Review of Anti-infective Therapy. 2012; 10(7): 815-828.

7. Torgerson PR, Macpherson CN. The socioeconomic burden of parasitic zoonoses: global trends. Vet Parasitol. 2011; 182: 79-95.

8. Hill D, Dubey JP. Toxoplasma gondii: transmission, diagnosis and prevention. Clinical microbiology and infection: the official publication of the European Society of Clinical Microbiology and Infectious Diseases. 2002; 8(10): 634-640. https://doi.org/10.1046/j.1469-0691.2002.00485.x

9. Dubey JP, Murata FHA, Cerqueira-Cézar CK, Kwok OCH, Villena I. Congenital toxoplasmosis in humans: an update of worldwide rate of congenital infections. Parasitology. 2021 Jun 18:1-11. doi: $10.1017 /$ S0031182021001013.

10. Costa GB, De Oliveira MC, Gadelha SR, Albuquerque GR, Teixeira M, Raiol, M, et al. Infectious diseases during pregnancy in Brazil: seroprevalence and risk factors. J Infect Develop Countr. 2018; 12(8): 657-665. https://doi.org/10.3855/jidc. 9492

11. European Centre for Disease Prevention and Control. Congenital toxoplasmosis. In: ECDC. Annual epidemiological report for 2016. Stockholm: ECDC; 2019. Stockholm, June 2019 @ European Centre for Disease Prevention and Control, 2017. Available at www.ecdc.europa.eu/ en/publications-data/congenital-toxoplasmosis-annual-epidemiologicalreport- 2016 (Accessed 10 August 2020).

12. Ayi I, Edu SA, Apea-Kubi KA, Boamah D, Bosompem KM, Edoh D. Sero-epidemiology of toxoplasmosis amongst pregnant women in the greater accra region of Ghana. Ghana Med J. 2009; 43(3): 107-114. https://doi.org/10.4314/gmj.v43i3.55325

13. Song KJ, Shin JC, Shin HJ, Nam HW. Seroprevalence of toxoplasmosis in Korean pregnant women. Korean J Parasitol. 2005; 43(2): 69-71. https://doi.org/10.3347/kjp.2005.43.2.69

14. Pinto B, Castagna B, Mattei R, Bruzzi R, Chiumiento L, Cristofani R, Buffolano W, Bruschi F. Seroprevalence for toxoplasmosis in individuals living in north west Tuscany: access to toxo-test 
in central Italy. Eur J Clin Microbiol Infect Dis. 2012; 31: 1151-1156.

15. Smith KL, Wilson M, Hightower AW, Kelley PW, Struewing JP, Juranek DD, McAuley JB. Prevalence of Toxoplasma gondii antibodies in US military recruits in 1989: comparison with data published in 1965. Clinical infectious diseases: an official publication of the Infectious Diseases Society of America. 1996; 23(5), 1182-1183. https://doi.org/10.1093/clinids/23.5.1182

16. Al-Shammari N, lqbal J. Decreasing trend in Toxoplasma seroprevalence among pregnant women in Kuwait. East Mediterr Health. 2021; 27 (1).

17. Mahfouz MS, Elmahdy M, Bahri A, Mobarki YM, Altalhi AA, Barkat NA, Al-Essa HA, et al. Knowledge and Attitude Regarding Toxoplasmosis among Jazan University Female Students. Saudi J Med Med Sci. 2019; 7(1): 28-32. doi: 10.4103/sjmms.sjmms_33_17. Epub 2018 Dec 14. PMID: 30787854; PMCID: PMC6381842.

18. Al-Hakami AM, Paul E, Al-Abed F, Alzoani AA, Shati AA, Assiri MI, et al. Prevalence of toxoplasmosis, rubella, cytomegalovirus, and herpes $(\mathrm{TORCH})$ infections among women attending the antenatal care clinic, maternity hospital in Abha, Southwestern Saudi Arabia. Saudi Med J. 2020; 41(7): 757-762. https://doi.org/10.15537/smj.2020.7.25121

19. The Public Authority for Civil Information, Kuwait, 2020. http://stat.paci.gov.kw/englishreports/\#DataTabPlace:ColumnChartGendrAge. Accessed on April 2021

20. Al-Nakib W, Ibrahim ME, Hathout H, Moussa MA, Deverajan LV, Thorburn H, Yousof AM. Seroepidemiology of viral and toxoplasma infections during pregnancy among Arab women of childbearing age in Kuwait. Inter J Epidemiol. 1983; 12(2): 220-223. https://doi.org/10.1093/ije/12.2.220

21. Al-Mulhim AA, Al-Qureshi AM. Sero-prevalence of toxoplasmosis in pregnant mothers and newborn infants in eastern province, Saudi Arabia. J Family \& Comm Med. 2001; 8(1): 45-48.

22. Iqbal J, Khalid N. Detection of acute Toxoplasma gondii infection in early pregnancy by IgG avidity and PCR analysis. J Med Microbiol. 2007; 56: 1495-1499. https://doi.org/10.1099/jmm.0.47260-0

23. Epi Info ${ }^{\mathrm{TM}}$ | CDC. https://www.cdc.gov/epiinfo/index.html

24. Bigna JJ, Tochie JN, Tounouga DN, Bekolo AO, Ymele NS, Youda EL, et al. Global, regional, and country seroprevalence of Toxoplasma gondii in pregnant women: a systematic review, modelling and meta-analysis. Sci Rep. 2020; 10: 12102. https://doi.org/10.1038/s41598-020-69078-9

25. Rahmanian V, Rahmanian K, Jahromi AS, Bokaie S. Seroprevalence of Toxoplasma gondii infection: An umbrella review of updated systematic reviews and meta-analyses. Review J Family Med Prim Care. 2020; 25: 3848-3855. doi: 10.4103/jfmpc.jfmpc_753_20. eCollection 2020 Aug.

26. Nayeri T, Sarvi S, Moosazadeh M, Amouei A, Hosseininejad Z, Daryani A. The global seroprevalence of anti-Toxoplasma gondii antibodies in women who had spontaneous abortion: A systematic review and meta-analysis. PLoS Negl Trop Dis. 2020 Mar 13;14(3):e0008103. doi: 10.1371/journal.pntd.0008103. PMID: 32168351; PMCID: PMC7069604. 
27. Al-Yami FS, Dar FK, Yousef Al, Al-Qurouni BH, Al-Jamea LH, Rabaan AA, Quiambao JV, Arulanantham ZJ, Woodman A. A pilot study on screening for gestational/congenital toxoplasmosis of pregnant women at delivery in the Eastern Province of Saudi Arabia. Saudi Pharm J. 2021 Apr;29(4):343-350. doi: 10.1016/j.jsps.2021.03.009. Epub 2021 Mar 25. PMID: 33994829; PMCID: PMC8093533.

28. Qamer S, Rizvi SSR, Raoof S, Kamal SM, Khan S. Sero-prevalence of toxoplasmosis among pregnant women attending an ante-natal clinic at a teaching hospital in Al Kharj, Saudi Arabia. Trop Biomed. 2020 Mar 1;37(1):186-193. PMID: 33612729.

29. Alzaheb RA. Seroprevalence of Toxoplasma gondii and its associated risk factors among women of reproductive age in Saudi Arabia: a systematic review and meta-analysis. Review Int J Womens Health. 2018;10: 537-544. doi: 10.2147/IJWH.S173640. eCollection 2018.

30. Alsammani MA. Sero-epidemiology and risk factors for Toxoplasma gondii among pregnant women in Arab and African countries. J Parasit Dis. 2016 Sep;40(3):569-79. doi: 10.1007/s12639-014-05588. Epub 2014 Sep 20. PMID: 27605750; PMCID: PMC4996171.

31. Elsafi SH, Al-Mutairi WF, Al-Jubran KM, Abu Hassan MM, Al Zahrani EM. Toxoplasmosis seroprevalence in relation to knowledge and practice among pregnant women in Dhahran, Saudi Arabia. Pathog Glob Health. 2015;109(8): 377-382. doi: 10.1080/20477724.2015.1103502. PMID: 26924348; PMCID: PMC4809232.

32. Almushait MA, Dajem SM, Elsherbiny NM, Eskandar MA, Al Azraqi TA, Makhlouf LM. Seroprevalence and risk factors of Toxoplasma gondii infection among pregnant women in south western, Saudi Arabia. J Parasit Dis. 2014; 38(1): 4-10. doi: 10.1007/s12639-012-0195-z. Epub 2012 Nov 2. PMID: 24505169; PMCID: PMC3909581.

33. Abu-Madi MAA, Behnke JM, Dabritz HA. Toxoplasma gondii seropositivity and co-infection with TORCH pathogens in high-risk patients from Qatar. Am J Trop Med Hyg. 2010; 82(4):626-633. doi: 10.4269/ajtmh.2010.09-0530.

34. Tabbara KS, Saleh F. Serodiagnosis of toxoplasmosis in Bahrain. Saudi Med J. 2005; 26(9): 13831387. PMID: 16155652.

35. Dar FK, Alkarmi T, Uduman S, Abdulrazzaq Y, Grundsell H, Hughes P. Gestational and neonatal toxoplasmosis: regional seroprevalence in the United Arab Emirates. Eur J Epidemiol. 1997 Jul;13(5):567-71. doi: 10.1023/a:1007392703037. PMID: 9258570.

36. AL-Sadoon MA, Nasir MA, Yasir ET; Khalaf AO, Kadim SJ. Toxoplasmosis and risk factors among female students of medical colleges at Basra University, Iraq. Biomed Pharmocol J. 2018; 11(4): 2117-2122.

37. Al Saadyi HAM, Al-Abbooddi A, Abbood ES. Sero-epidemiology of Toxoplasma gondii among men and pregnant women in Maysan Province, south of Iraq. Iran. J. Ichthyol. (ICAEAS special issue 2021): 27-37. P-ISSN: 2383-1561; E-ISSN: 2383-0964

38. Nahouli H, El Arnaout N, Chalhoub E, Anastadiadis E, El Hajj H. Seroprevalence of Anti-Toxoplasma gondii Antibodies Among Lebanese Pregnant Women. Vector Borne Zoonotic Dis. 2017 Dec;17(12): 785-790. doi: 10.1089/vbz.2016.2092. Epub 2017 Oct 24. PMID: 29064352. 
39. Obaidat MM, Al-Sheyab NA, Bani Salman AE, Lafi SQ. Seroepidemiology and risk factors of Toxoplasma gondii infection in undergraduate university female students in Jordan. Epidemiol Infect. 2015 Jul;143(9):1898-903. doi: 10.1017/S0950268814003604. Epub 2014 Dec 29. PMID: 25543692.

40. Shahighi M, Heidari A, Keshavarz H, Bairami A, Shojaee S, Sezavar M, Salimi M, Teimouri A. Seroepidemiological study of toxoplasmosis in women referred to a pre-marriage counseling center in Alborz Province, Iran. BMC Res Notes. 2021 Apr 30;14(1):163. doi: 10.1186/s13104-021-05581-0. PMID: 33931121; PMCID: PMC8086314.

41. Raissi V, Taghipour A, Navi Z, Etemadi S, Sohrabi Z, Sohrabi N, et al. Seroprevalence of Toxoplasma gondii and Toxocara spp. infections among pregnant women with and without previous abortions in the west of Iran. J Obstet Gynaecol Res. 2020; 46: 382-388. doi:10.1111/jog.14184.

42. Malary M, Hamzehgardeshi Z, Moosazadeh M, Afshari M, Ahmadi I, et al. Seroprevalence of Toxoplasma gondii infection among Iranian pregnant women: a systematic review and metaanalysis. East Mediterr Health J. 2018; 17;24(5): 488-496. doi: 10.26719/2018.24.5.488.

43. Nijem KI, Al-Amleh S. Seroprevalence and associated risk factors of toxoplasmosis in pregnant women in Hebron district, Palestine. East Mediterr Health. 2009; 15 (5):, $1278-$ 1284. https://apps.who.int/iris/handle/10665/117759

44. Halici-Ozturk F, Yakut K, Öcal FD, Erol A, Gökay S, Çağlar AT, Engin-Üstün Y, Ozgu-Erdinc AS. Seroprevalence of Toxoplasma gondii infections in Syrian pregnant refugee women in Turkey. Eur $\mathrm{J}$ Obstet Gynecol Reprod Biol. 2021; 256: 91-94. doi: 10.1016/j.ejogrb.2020.11.002. Epub 2020 Nov 6. PMID: 33188994.

45. Durukan H, Çevikoğlu Kıllı M. Retrospective Evaluation of the Seropositivity Rate of Toxoplasmosis and Clinical Results in Pregnant Women That were Admitted to a Tertiary Health Institution Between 2012 and 2017 in Turkey. Turkiye Parazitol Derg. 2019; 43(3):106-110. doi:

10.4274/tpd.galenos.2019.6373. PMID: 31502771.

46. Kajeguka DC, Anderson M, Mawazo A, Mgabo M. Sero-epidemiology of Toxoplasma gondii and risk factors among pregnant women in Africa. Research Square. 2021; DOI: 10.21203/rs.2.18914/v2

47. Abdelbaset AE, Hamed MI, Abushahba MFN, Rawy MS, Sayed ASM, Adamovicz JJ. Toxoplasma gondii seropositivity and the associated risk factors in sheep and pregnant women in El-Minya Governorate, Egypt. Vet World. 2020; 13(1): 54-60. doi: 10.14202/vetworld.2020.54-60. Epub 2020 Jan 9. PMID: 32158151; PMCID: PMC7020121.

48. Ibrahim HM, Mohamed AH, El-Sharaawy AA, El-Shqanqery HE. Molecular and serological prevalence of Toxoplasma gondii in pregnant women and sheep in Egypt. Asian Pac J Trop Med. 2017; 10(10): 996-1001. doi: 10.1016/j.apjtm.2017.09.012. Epub 2017 Sep 19. PMID: 29111196.

49. Zakari MM, Isah AY, Offiong R, Yunusa T, Abdullahi IN. Serological survey and risk factors associated with Toxoplasma gondii infection among HIV-infected pregnant women attending Abuja Tertiary Hospital, Nigeria. Malawi Med J. 2020; 32(3): 160-167. doi: 10.4314/mmj.v32i3.9. 
50. Laboudi M, Taghy Z, Duieb O, Peyron F, Sadak A. Toxoplasma gondii seroprevalence among pregnant women in Rabat, Morocco. Trop Med Health. 2021; 49(1): 21. doi: 10.1186/s41182-02100311-5. PMID: 33685529; PMCID: PMC7941977.

51. Al-Adhroey AH, Mehrass AAO, Al-Shammakh AA, Ali AD, Akabat MYM, Al-Mekhlafi HM. Prevalence and predictors of Toxoplasma gondii infection in pregnant women from Dhamar, Yemen. BMC Infect Dis. 2019; 19(1): 1089. doi: 10.1186/s12879-019-4718-4. PMID: 31888517; PMCID: PMC6937662.

52. Mahmoud AS, Alarwiy AO, Ganghish KS, Alhares A, Sabei L, Altaesh M, Algeriany M. Seroprevalence and potential risk factors associated with Toxoplasma gondii infection in women from Tripoli, Libya. Am J Prevent Med \& Pub Health. 2019; 5 (3): 45-49. 10.5455/ajpmph.20190625055602

53. Amin TT, Ali MN, Alrashid AA, Al-Agnam AA, Al Sultan AA. Toxoplasmosis preventive behavior and related knowledge among Saudi pregnant women: an exploratory study. Glob J Health Sci. 2013; 5(5): 131-143. doi:10.5539/gjhs.v5n5p131

54. Senosy SA. Knowledge and attitudes about toxoplasmosis among female university students in Egypt. Int J Adolesc Med Health. 2020 Feb 28:/j/ijamh.ahead-of-print/ijamh-2019-0207/ijamh-20190207.xml. doi: 10.1515/ijamh-2019-0207. Epub ahead of print. PMID: 32109206.

55. Onduru OG, Rumisha SF, Munyeme M, Phiri AM. Evaluation of the level of awareness of congenital toxoplasmosis and associated practices among pregnant women and health workers in Tanzania's Temeke district in Dar es Salaam. Afr Health Sci. 2019 Dec; 19(4): 3027-3037. doi: 10.4314/ahs.v19i4.24. PMID: 32127878; PMCID: PMC7040330.

56. Ouzennou N, Boussaa S, Alla SB, Boumezzough A. Observational study to assess pregnant women's knowledge and behaviour related to toxoplasmosis in Essaouira province, Morocco. Asian Pac Trop Med. 2019; 12: 87-90.

57. Baghlaninezhad R, Beiromvand M, Veisi MS. Analysis of knowledge and attitudes related to parasitic infections among inhabitants of Ahvaz County, Khuzestan Province, Iran. Acta Trop. 2019; 193: 211216. doi: 10.1016/j.actatropica.2019.03.014. Epub 2019 Mar 11. PMID: 30871988.

58. Charafeddine L, El Rafei R, Azizi S, Sinno D, Alamiddine K, Howson CP, Walani SR, Ammar W, Nassar A, Yunis K. Improving awareness of preconception health among adolescents: experience of a school-based intervention in Lebanon. BMC Public Health. 2014 Jul 31;14:774. doi: 10.1186/14712458-14-774. PMID: 25081733; PMCID: PMC4246486.

59. Al-Sheyab NA, Obaidat MM, Bani Salman AE, Lafi SQ. Toxoplasmosis-Related Knowledge and Preventive Practices among Undergraduate Female Students in Jordan. J Food Prot. 2015 Jun; 78(6): 1161-6. doi: 10.4315/0362-028X.JFP-14-579.PMID: 26038907

60. Sweileh WM, Jodeh DS, Ruzieh IS. Toxoplasmosis-Related Knowledge and Preventive Practices among Undergraduate Female Students at An-Najah National University, Palestine. IUG J Naural Sciences. 2017; 25 (3): 45-52.

61. Hamou S A, Laboudi M. An analytical study on the awareness and practice relating toxoplasmosis among pregnant women in Casablanca, Morocco. BMC Public Health. 2021 Mar 16;21(1):507. doi: 10.1186/s12889-021-10474-9. PMID: 33726705; PMCID: PMC7962262. 
62. Martini A, Pietrafesa E, Rondinone BM, lavicoli S, D'amelio S, Cavallero S, Bonafede M. Toxoplasmosis and knowledge: what do the Italian women know about? Epidemiol Infect. 2020; 7: 148:e256. doi: 10.1017/S0950268820002393. PMID: 33023706; PMCID: PMC7689595.

63. Mayada KM, Nabila K. Assessment of knowledge and practice among females about toxoplasmosis. Tikrit Med J. 2017; 23 (1): 140-151. www.iasj.net/iasj?func=fulltext\&ald=178210 (Accessed 10 August 2020).

64. Andiappan H, Nissapatorn V, Sawangjaroen N, Khaing SL, Salibay CC, Cheung MM, Dungca JZ, Chemoh W, Xiao Teng C, Lau YL, Mat Adenan NA. Knowledge and practice on Toxoplasma infection in pregnant women from Malaysia, Philippines, and Thailand. Front Microbiol. 2014 Jun 11;5:291. doi: 10.3389/fmicb.2014.00291. PMID: 24966855; PMCID: PMC4052801.

65. Jones JL, Ogunmodede F, Scheftel J, Kirkland E, Lopez A, Schulkin J, Lynfield R. Toxoplasmosisrelated knowledge and practices among pregnant women in the United States. Infect Dis Obstet Gynecol. 2003;11(3):139-45. doi: 10.1080/10647440300025512. PMID: 15022874; PMCID: PMC1852280.

66. Pereboom MT, Manniën J, Spelten ER, Schellevis FG, Hutton EK. Observational study to assess pregnant women's knowledge and behaviour to prevent toxoplasmosis, listeriosis and cytomegalovirus. BMC Pregnancy Childbirth. 2013 Apr 30;13:98. doi: 10.1186/1471-2393-13-98. PMID: 23627427; PMCID: PMC3644250.

67. Ogunmodede F, Scheftel J, Jones JL, Lynfield R. Toxoplasmosis prevention knowledge among pregnant women in Minnesota. Minn Med. 2005 Feb;88(2):32-4. PMID: 17886796.

68. Moura FL de, Millar PR, Fonseca ABM, Amendoeira MRR. Congenital toxoplasmosis: perception of knowledge and primary prevention measures among healthcare professionals and pregnant women treated in public healthcare facilities. Scientia Medica, 2017; ISSN-e 1980-6108, Vol. 27, № 1 ID25389. oai:doaj.org/article:ff5eef947ca94037904411b31e628f0c

69. Moura FL, Goulart PR, Moura AP, Souza TS, Fonseca AB, Amendoeira MR. Factors associated to toxoplasmosis-related knowledge among pregnant women attending public health services in the municipality of Niterói, Rio de Janeiro, Brazil, 2013-2015. Epidemiol Serv Saude. 2016 JulSep;25(3):655-661. English, Portuguese. doi: 10.5123/S1679-49742016000300022. PMID: 27869937.

70. Smereka J, Szarpak L, Ruetzler K, Schacham Y, Smereka A, Dabrowski M, Terpilowska M, Terpilowski L, Adam I. A multicenter survey on toxoplasmosis knowledge among pregnant women in Poland (the TOWER study). BMC Pregnancy Childbirth. 2018 Oct 3;18(1):389. doi: 10.1186/s12884-018-2031-7. PMID: 30285660; PMCID: PMC6171245

\section{Tables}

Table 1. Knowledge about Toxoplasma gondii, and epidemiological, clinical aspects and preventive attitude of women with/without pregnancy experience towards toxoplasmosis. 
Question

Never Pregnant-at least-once

Pregnant

PEG, $n=212 \quad n(\%)$

p-value

NPG,

$\mathrm{n}=200 \mathrm{n}$

(\%)

Which of the following would prevent you from getting toxoplasmosis

Not changing the cat's litter box

68

$(34.0 \%)$

$102(48.1 \%)$

$0.004^{*}$

Cooking meat well

60

$(30.0 \%)$

$97(45.8 \%)$

$0.001^{*}$

Thoroughly washing fruits/vegetables

30

$(15.0 \%)$

$45(21.1 \%)$

0.102

Gardening with gloves

31

$(15.5 \%)$

None

132

$(66.0 \%)$

$24(11.3 \%)$

0.213

$98(46.2 \%)$

$0.000 *$

What is your attitude toward Toxoplasmosis?

\begin{tabular}{llll}
\hline Nothing & $\begin{array}{l}113 \\
(56.5 \%)\end{array}$ & $96(45.3 \%)$ & $0.023^{*}$ \\
\hline It is dangerous & $\begin{array}{l}74 \\
(37.0 \%)\end{array}$ & $99(46.7 \%)$ & $0.046^{*}$ \\
\hline Causes symptoms & $\begin{array}{l}46 \\
(23.0 \%)\end{array}$ & $48(22.6 \%)$ & 0.931 \\
\hline Affects pregnant women only & $18(9.0 \%)$ & $10(4.7 \%)$ & 0.084 \\
\hline $\begin{array}{l}\text { Can be transmitted by unwashed } \\
\text { vegetables and under- cooked meat }\end{array}$ & $\begin{array}{l}35 \\
(17.5 \%)\end{array}$ & $41(19.3 \%)$ & 0.630 \\
\hline Can be transmitted by blood transfusion & $\begin{array}{l}24 \\
(12.0 \%)\end{array}$ & $10(4.7 \%)$ & $0.007 *$ \\
\hline Can cause miscarriage or stillbirth & $\begin{array}{l}67 \\
(33.5 \%)\end{array}$ & $87(41.0 \%)$ & 0.114 \\
\hline $\begin{array}{l}\text { Can be transmitted from pregnant woman } \\
\text { to her fetus }\end{array}$ & $\begin{array}{l}34 \\
(17.0 \%)\end{array}$ & $37(17.5 \%)$ & 0.903 \\
\hline
\end{tabular}

Table 2. Seroprevalence of Toxoplasma gondii IgG and IgM antibodies and associated risk factor among pregnant women \& women of childbearing age in the Eastern Mediterranean \& African Region. 


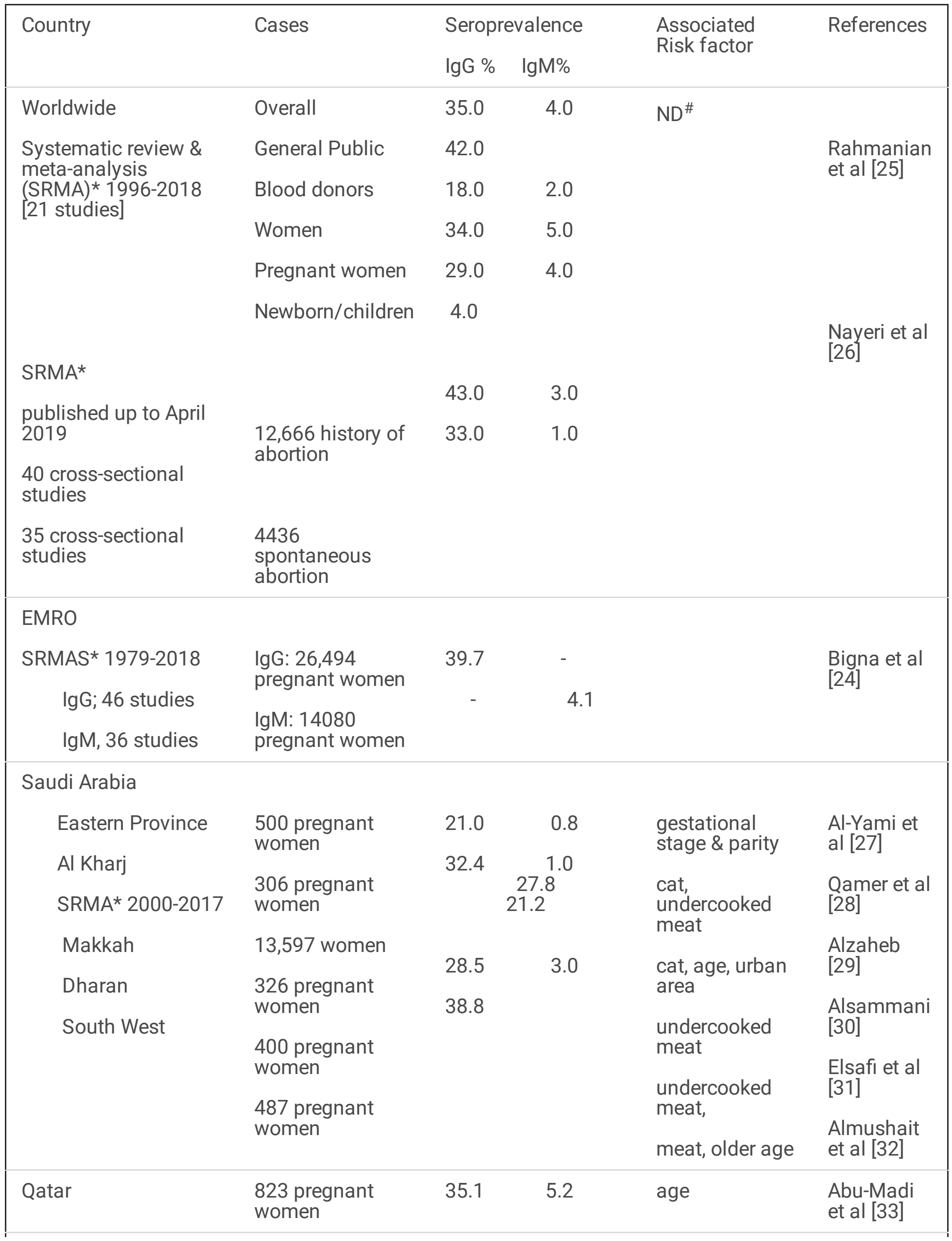




\begin{tabular}{|c|c|c|c|c|c|}
\hline $\begin{array}{l}\text { Bahrain } \\
\text { 2000-2003 }\end{array}$ & $\begin{array}{l}4,739 \text { pregnant } \\
\text { women }\end{array}$ & 21.8 & 10.3 & cat & $\begin{array}{l}\text { Tabbara \& } \\
\text { Saleh [34] }\end{array}$ \\
\hline UAE & $\begin{array}{l}1503 \text { pregnant } \\
\text { women }\end{array}$ & 22.9 & 3.1 & ND & $\begin{array}{l}\text { Dar et al } \\
\text { [35] }\end{array}$ \\
\hline \multicolumn{6}{|l|}{ Iraq } \\
\hline & $\begin{array}{l}177 \text { university } \\
\text { students }\end{array}$ & \multicolumn{2}{|l|}{12.4} & $\begin{array}{l}\text { cat, raw } \\
\text { vegetable/meat }\end{array}$ & $\begin{array}{l}\text { Al-Sadoon } \\
\text { et al [36] }\end{array}$ \\
\hline Ivlayson & 48 women & 27.1 & & ND & $\begin{array}{l}\text { Al-Saadyi } \\
\text { et al [37] }\end{array}$ \\
\hline \multirow{2}{*}{$\begin{array}{l}\text { Kuwait } \\
\text { Kuwait }\end{array}$} & $\begin{array}{l}224 \text { pregnant } \\
\text { women }\end{array}$ & 53.1 & 13.8 & ND & $\begin{array}{l}\text { Iqbal \& } \\
\text { Khalid [22] }\end{array}$ \\
\hline & $\begin{array}{l}280 \text { pregnant } \\
\text { women }\end{array}$ & 12.5 & 2.1 & $\begin{array}{l}\text { no risk factor } \\
\text { detected }\end{array}$ & $\begin{array}{l}\text { Al- } \\
\text { Shammari } \\
\text { \& Iqbal [16] }\end{array}$ \\
\hline $\begin{array}{l}\text { Beirut, Lebanon } \\
\text { Retrospective cohort } \\
\text { 1994-2015 }\end{array}$ & $\begin{array}{l}2456 \text { pregnant } \\
\text { women }\end{array}$ & 82.6 & 1.8 & $N D^{\#}$ & $\begin{array}{l}\text { Nahouli et } \\
\text { al [38] }\end{array}$ \\
\hline Jordan & $\begin{array}{l}220 \text { pregnant } \\
\text { women }\end{array}$ & 66.5 & 0.5 & $\begin{array}{l}\text { older age, } \\
\text { undercooked } \\
\text { meat }\end{array}$ & $\begin{array}{l}\text { Obaidat et } \\
\text { al [39] }\end{array}$ \\
\hline \multicolumn{6}{|l|}{ Iran } \\
\hline Alborz Province & 400 women & 20.1 & 8.7 & older age, cat, & \multirow{2}{*}{$\begin{array}{l}\text { Shahighi et } \\
\text { al [40] }\end{array}$} \\
\hline Western region & $\begin{array}{l}189 \text { pregnant } \\
\text { women }\end{array}$ & 39.7 & - & meat, cat & \\
\hline $\begin{array}{l}\text { SRMA*, } 43 \\
\text { studies }\end{array}$ & \multirow{2}{*}{$\begin{array}{l}22644 \text { pregnant } \\
\text { women }\end{array}$} & 39.2 & 4.0 & ND & $\begin{array}{l}\text { Raissi et al } \\
{[41]}\end{array}$ \\
\hline 1990-2015 & & & & & $\begin{array}{l}\text { Malary et } \\
\text { al [42] }\end{array}$ \\
\hline Hebron, Palestine & $\begin{array}{l}204 \text { pregnant } \\
\text { women }\end{array}$ & 27.9 & 17.6 & $\begin{array}{l}\text { cat, raw } \\
\text { vegetable/meat }\end{array}$ & $\begin{array}{l}\text { Nijem \& Al- } \\
\text { Amleh [43] }\end{array}$ \\
\hline $\begin{array}{l}\text { Syria } \\
\text { Refugees in Turkey }\end{array}$ & $\begin{array}{l}754 \text { pregnant } \\
\text { women }\end{array}$ & 47.0 & 0.4 & ND & $\begin{array}{l}\text { Halici- } \\
\text { Ozturk et al } \\
\text { [44] }\end{array}$ \\
\hline $\begin{array}{l}\text { Turkey } \\
\text { 2012-2017 }\end{array}$ & 3474 women & 44.2 & 7.7 & ND & $\begin{array}{l}\text { Durukan et } \\
\text { al [45] }\end{array}$ \\
\hline \multicolumn{6}{|l|}{ Africa } \\
\hline SRMA* 2001-2019 & $\begin{array}{l}10,701 \text { pregnant } \\
\text { women }\end{array}$ & 65.1 & & cat, raw meat & $\begin{array}{l}\text { Kajeguka } \\
\text { et al [46] }\end{array}$ \\
\hline
\end{tabular}




\begin{tabular}{|c|c|c|c|c|c|}
\hline Central & & 50.2 & & & \\
\hline Eastern & & 47.8 & & & \\
\hline Northern & & 38.3 & & & \\
\hline Western & & & & & \\
\hline & $\begin{array}{l}96 \text { pregnant } \\
\text { women }\end{array}$ & 22.9 & - & $\begin{array}{l}\text { cat, older age, } \\
\text { undercooked }\end{array}$ & $\begin{array}{l}\text { Abdelbaset } \\
\text { et al [47] }\end{array}$ \\
\hline  & $\begin{array}{l}364 \text { pregnant } \\
\text { women }\end{array}$ & 30.0 & & same as above & $\begin{array}{l}\text { Ibrahim et } \\
\text { al [48] }\end{array}$ \\
\hline Nigeria & 317 women & 28.8 & 3.8 & $\begin{array}{l}\text { no risk factor } \\
\text { detected }\end{array}$ & $\begin{array}{l}\text { Zakari et al } \\
\text { [49] }\end{array}$ \\
\hline Rabat, Morocco & $\begin{array}{l}576 \text { pregnant } \\
\text { women }\end{array}$ & 43.0 & 3.9 & older age & $\begin{array}{l}\text { Laboudi et } \\
\text { al [50] }\end{array}$ \\
\hline Dhamar, Yemen & 420 women & 20.0 & 1.2 & $\begin{array}{l}\text { cat, raw } \\
\text { vegetables, } \\
\text { spontaneous } \\
\text { abortion }\end{array}$ & $\begin{array}{l}\text { Al-Adhroey } \\
\text { et al [51] }\end{array}$ \\
\hline Tripoli, Libya & 500 women & 50.8 & - & $\begin{array}{l}\text { age, cat, raw } \\
\text { vegetable, rural } \\
\text { area }\end{array}$ & $\begin{array}{l}\text { Mahmoud } \\
\text { et al [52] }\end{array}$ \\
\hline
\end{tabular}

* SRMA, Systematic review \& meta-analysis; \# ND, not done; **NA, not available

Table 3. Knowledge, attitude and practices towards toxoplasmosis among pregnant women \& women of childbearing age in the Eastern Mediterranean \& African Region. 


\begin{tabular}{|c|c|c|c|c|}
\hline Country & $\begin{array}{l}\text { Sample size \& } \\
\text { Target group }\end{array}$ & KAP & $\begin{array}{l}\text { Predictors for } \\
\text { KAP }\end{array}$ & References \\
\hline \multicolumn{5}{|l|}{ Saudi Arabia } \\
\hline Al Hassa & $\begin{array}{l}234 \text { pregnant } \\
\text { women }\end{array}$ & $73.2 \%$ no knowledge & $\begin{array}{l}\text { Old age, } \\
\text { education, h/o } \\
\text { abortion }\end{array}$ & Amin et al [53] \\
\hline Dharan & \multirow{2}{*}{$\begin{array}{l}400 \text { pregnant } \\
\text { women }\end{array}$} & 75.5 never heard & ND & Elsafi et al [31] \\
\hline \multirow[t]{2}{*}{ Jazan } & & \multirow[t]{2}{*}{79.1 no knowledge } & \multirow[t]{2}{*}{ ND } & \multirow{2}{*}{$\begin{array}{l}\text { Mahfouz et al } \\
\text { [17] }\end{array}$} \\
\hline & $\begin{array}{l}400 \text { Female } \\
\text { students }\end{array}$ & & & \\
\hline Ahvaz, Iran & $\begin{array}{l}31.3 \text { General } \\
\text { public }\end{array}$ & 1735 women & NA & $\begin{array}{l}\text { Baghlaninezhad } \\
\text { et al [57] }\end{array}$ \\
\hline Lebanon & $\begin{array}{l}\text { 7, } 290 \text { School } \\
\text { students }\end{array}$ & & ND & $\begin{array}{l}\text { Caharafeddine } \\
\text { et al [58] }\end{array}$ \\
\hline Egypt & \multirow{2}{*}{$\begin{array}{l}1079 \text { University } \\
\text { female } \\
\text { students }\end{array}$} & $96.8 \%$ low knowledge & \multirow[t]{2}{*}{ ND } & \multirow[t]{2}{*}{ Senosy [54] } \\
\hline $\begin{array}{l}\text { Beni-Suef } \\
\text { Uni }\end{array}$ & & $63 \%$ negative attitude & & \\
\hline Mayson, Iraq & $\begin{array}{l}\text { Pregnant } \\
\text { women }\end{array}$ & $79.5 \%$ no knowledge & ND & $\begin{array}{l}\text { Al Saadyi et al } \\
\text { [37] }\end{array}$ \\
\hline Tanzania & $\begin{array}{l}371 \text { Pregnant } \\
\text { women }\end{array}$ & $96 \%$ unaware & $\begin{array}{l}70 \% \text { low } \\
\text { preventive } \\
\text { practice }\end{array}$ & $\begin{array}{l}\text { Onduru et al } \\
\text { [55] }\end{array}$ \\
\hline \multirow[t]{2}{*}{ Jordon } & $\begin{array}{l}280 \text { women } \\
\text { and }\end{array}$ & \multirow{2}{*}{$\begin{array}{l}51.1 \% \text { never heard, } 24.7 \text { - } \\
53.7 \text { some info }>50 \% \\
\text { +attitude }\end{array}$} & \multirow[t]{2}{*}{ ND } & \multirow[t]{2}{*}{$\begin{array}{l}\text { Al-Sheyab et al } \\
\text { [59] }\end{array}$} \\
\hline & $\begin{array}{l}1390 \text { Female } \\
\text { students }\end{array}$ & & & \\
\hline Palestine & \multirow{2}{*}{$\begin{array}{l}976 \text { Female } \\
\text { students }\end{array}$} & \multirow[t]{2}{*}{$51.1 \%$ never heard, } & \multirow{2}{*}{$\begin{array}{l}68.8 \% \\
\text { preventive } \\
\text { behavior }\end{array}$} & \multirow{2}{*}{$\begin{array}{l}\text { Sweileh et al } \\
\text { [60] }\end{array}$} \\
\hline Al Najah Uni & & & & \\
\hline \multicolumn{5}{|l|}{ Morocco } \\
\hline \multirow{2}{*}{ Essaouira, } & $\begin{array}{l}600 \text { pregnant } \\
\text { women }\end{array}$ & $97.3 \%$ no knowledge & \multirow{2}{*}{$\begin{array}{l}95 \% \text { preventive } \\
\text { behavior }\end{array}$} & $\begin{array}{l}\text { Ouzennou et al } \\
\text { [56] }\end{array}$ \\
\hline & $\begin{array}{l}390 \text { pregnant } \\
\text { women }\end{array}$ & $58.8 \%$ never heard & & $\begin{array}{l}\text { Hamou \& } \\
\text { Laboudi [61] }\end{array}$ \\
\hline
\end{tabular}

$\mathrm{ND}$, not determined

\section{Supplemental Note}


The Supplemental Files are not available with this version

\section{Figures}

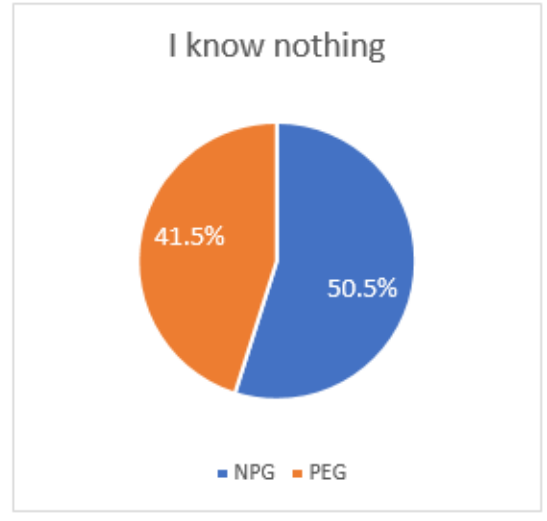

A

\section{Figure 1}

General knowledge towards Toxoplasma gondii infection among women with pregnancy experience group (PEG, $n=212$ ) and never-pregnant group (NPG, $n=200)$ to the online survey question 'what do you know about toxoplasmosis: I know nothing'. The PEG included 114 currently pregnant (CP) and 98 females with history of an earlier pregnancy (EP). Distribution of responses among the 414 target groups participating the online survey to the question 'what do you know about toxoplasmosis: I know nothing'. The high school girls were the least informed (36.6\%) compared to 1st Year medical students $(11.9 \%)$.

\section{What do you know about Toxoplasmosis}

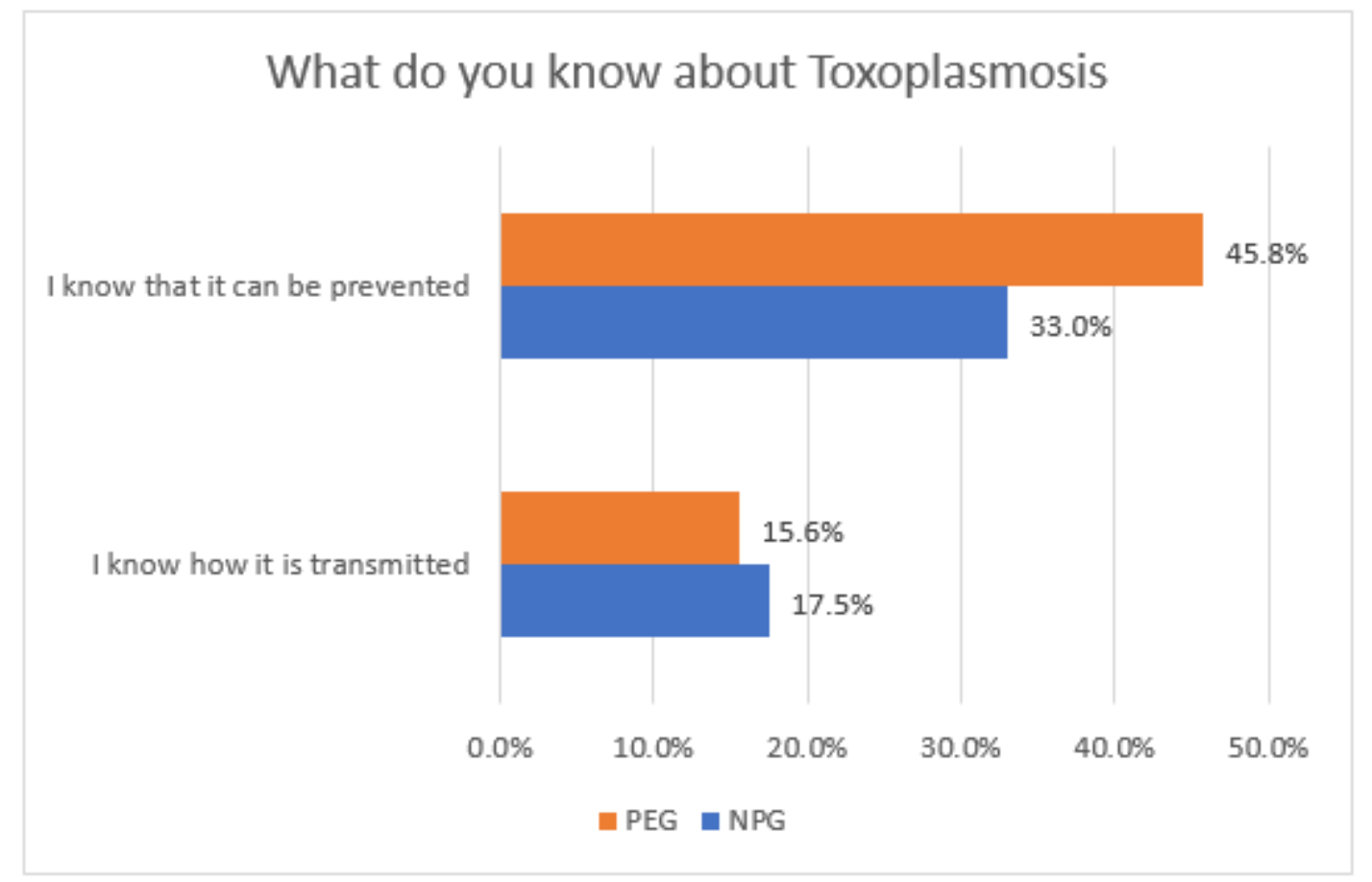

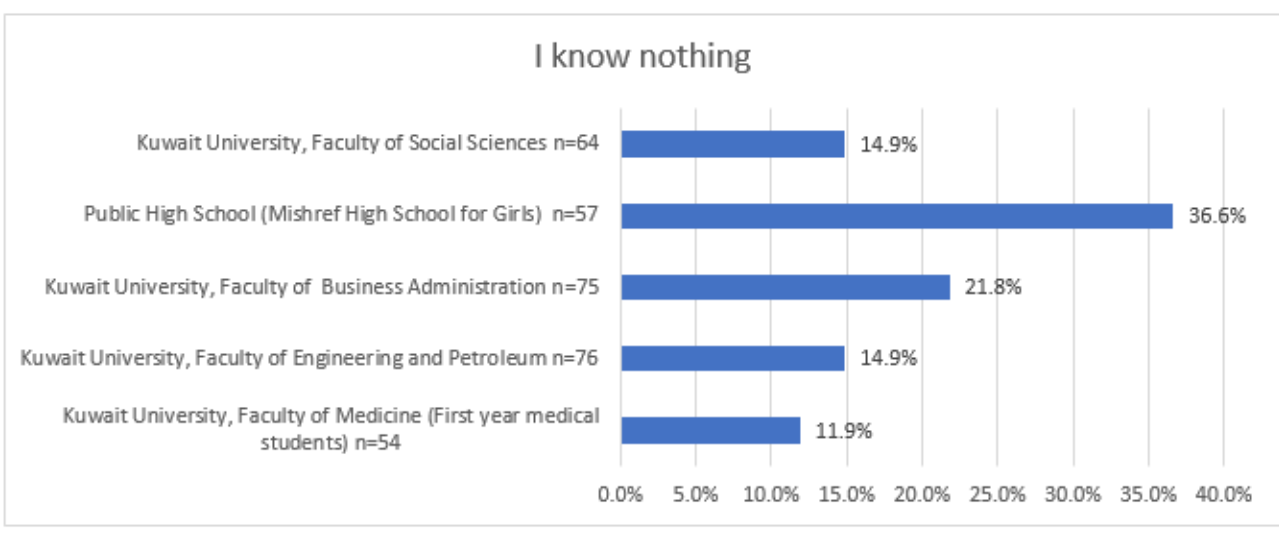

B

Figure 2 
Knowledge towards Toxoplasma gondii infection transmission and prevention among women with pregnancy experience group (PEG, $n=212$ ) and never-pregnant group (NPG, $n=200$ ) to the online survey questions 'I know how it is transmitted' and 'I know it can be prevented'.

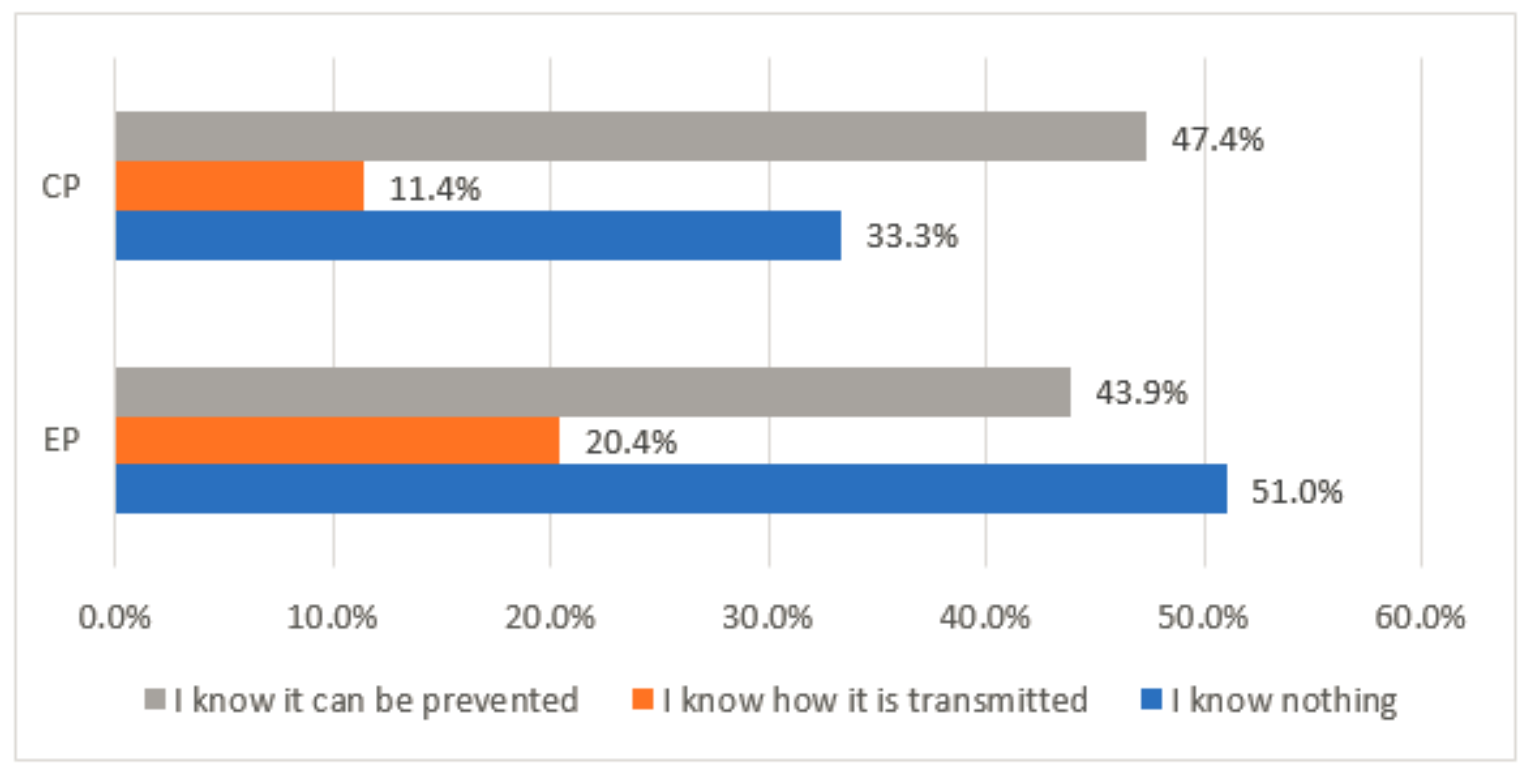

\section{Figure 3}

Knowledge towards Toxoplasma gondii infection, transmission and prevention among women with history of an earlier pregnancy (EP) and currently pregnant women (CP).

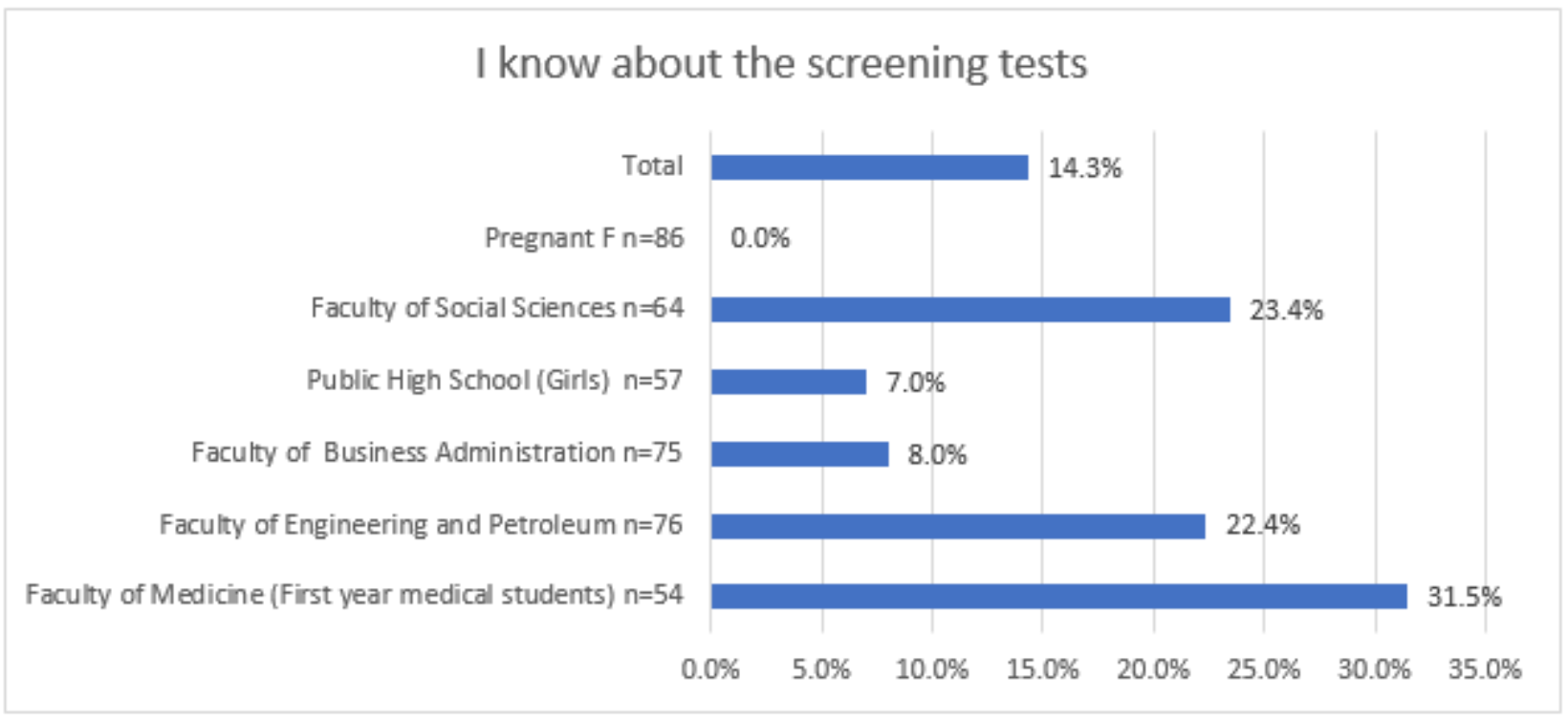

Figure 4

Distribution of responses among the 414 target groups participating the online survey to the question 'I know about the screening tests to T. gondii infection'. None of the pregnant women attending the antenatal clinic among the 86 pregnant women attending the antenatal clinic knew about the screening tests. 


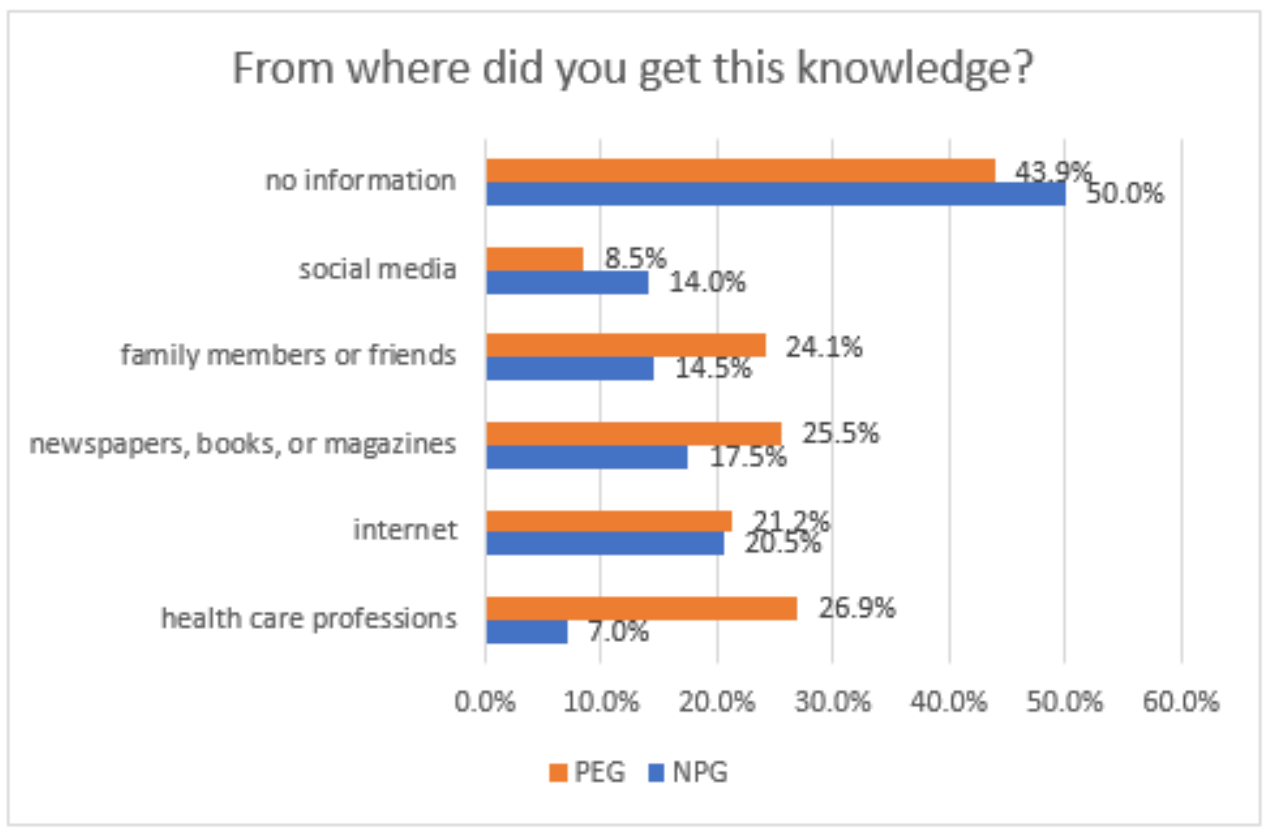

\section{Figure 5}

The source of knowledge among women with pregnancy experience group (PEG, $n=212$ ) and neverpregnant group (NPG, $n=200$ ). A significantly higher number of women in PEG got this information from health care professionals and family members and friends. Social media was the least source of information for all the groups. 